\title{
ASSESSMENT OF BODY SURFACE TEMPERATURE IN CETACEANS: AN ITERATIVE APPROACH
}

\author{
SILVA, R. G. \\ Departamento de Ciência Animal, Universidade Estadual Paulista, \\ CEP 14884-900, Jaboticabal, SP, Brazil \\ Correspondece to: Roberto Gomes da Silva, Departamento de Ciência Animal, Universidade Estadual Paulista, \\ CEP 14884-900, Jaboticabal, SP, Brazil, e-mail: rgomes@ fcav.unesp.br \\ Received March 7, 2003 - Accepted July 11, 2003 - Distributed August 31, 2004 \\ (With 2 figures)
}

\begin{abstract}
Heat transfer from skin surface to ambient water is probably the most important aspect of thermal balance in marine mammals, but the respective calculations depend on knowing the surface temperature $\left(T_{\mathrm{S}}\right)$, the direct measurement of which in free animals is very difficult. An indirect iterative method is proposed for $T_{\mathrm{S}}$ prediction in free cetaceans from deep body temperature, swimming speed, and temperature and thermodynamic properties of the water.
\end{abstract}

Key words: cetaceans, thermoregulation, skin temperature, prediction.

\section{RESUMO}

\section{Determinação da temperatura cutânea em cetáceos: uma abordagem iterativa}

A transferência de energia térmica da superfície corporal para a água é provavelmente o aspecto mais importante do equilíbrio térmico em mamíferos marinhos, mas os respectivos cálculos dependem do conhecimento da temperatura da superfície, $T_{\mathrm{s}}$, cuja medição direta em animais em liberdade constitui um problema difícil de resolver. Um método iterativo é proposto para a predição de $T_{\mathrm{S}}$ de cetáceos em liberdade, a partir da temperatura corporal profunda, da velocidade de deslocamento e da temperatura e propriedades termodinâmicas da água.

Palavras-chave: cetáceos, termorregulação, temperatura cutânea, predição.

\section{INTRODUCTION}

Cetaceans are the only homeotherms that spend their entire life in the open sea, subject to water temperatures ranging from $-2^{\circ} \mathrm{C}$ to about $30^{\circ} \mathrm{C}$. Thermal difficulties imposed by such a variable environment stem mostly from the high thermal conductivity of water, which results in rapid heat flow away from the body surface. Consequently, it is widely assumed that skin temperature of these bare-skinned animals is nearly the same as that of water (Irving \& Hart, 1957).

In general, endothermic animals minimize heat loss in cold environments by reducing skin temperature in order to maintain the least possible temperature differential. This reduction is achieved by low conduction of heat from the inner body tissues to the cutaneous surface. In cetaceans the main thermal barrier is a blubber layer covering most of the body. For example, a porpoise with $2 \mathrm{~cm}$ of blubber can sustain a deep body temperature $39^{\circ} \mathrm{C}$ higher than that of the ambient water.

While fur seals may present skin temperatures more than $20^{\circ} \mathrm{C}$ above that of ambient water (Boyd, 2000), bare-skinned dolphins have surface temperatures usually within $1^{\circ} \mathrm{C}$ of the water even after exercise in warm waters (Noren et al., 1999). Different models have been used to estimate heat exchange in marine mammals (Innes, 1986; Kshatriya \& Blake, 1988; Ryg et al., 1988; Hokkanen, 1990; Watts et al., 1993), but the results vary widely, which is probably explained by the practical difficulties 
entailed in measuring body surface temperature of these animals.

This paper presents an iterative method of predicting the skin temperature of cetaceans using deep body temperature, swimming speed, and the temperature and thermodynamic properties of the water.

\section{The model}

In the simplest terms, the body of a cetacean may be thermally considered as a cylinder of length $L$ with a uniformly warm core surrounded by an insulating blubber layer (Scholander et al., 1950; Watts et al., 1993), whose thickness is assumed to be uniform throughout the body. The inner body temperature is within the usual mammalian range of $35^{\circ}$ to $38^{\circ} \mathrm{C}$ (Kanwischer \& Leivestad, 1957; Morrison, 1962; Kanwischer \& Sundnes, 1966) and one can assume an average $37^{\circ} \mathrm{C}$ value without significant error. A cylindrical model, illustrated in Fig. 1, has also been supposed by other authors (Ryg et al., 1988; Lavigne et al., 1990; Watts et al., 1993).

Thermal balance is reached when heat input equates with heat loss. The thermal balance equation in cetaceans is very simple compared to that of terrestrial mammals. The only heat input results from metabolism (M), while heat is lost by conduction (K) from the inner body to the skin, from which heat passes by convection $(\mathbf{C})$ to ambient water:

$$
\mathbf{M}=\mathbf{C}+\mathbf{K}
$$

Latent heat loss by evaporation in the respiratory tract, as observed in most mammals, is another way to transfer thermal energy, but cetaceans spend much time under water, emerging at intervals for respiration. Thus, heat loss by respiratory evaporation is low, i.e., less than $6 \%$ of total body heat loss (Kanwischer \& Sundnes, 1966; Folkow \& Blix, 1992). On the other hand, fins and flippers are regarded as efficient cooling surfaces because they have little or no insulation and a rich blood supply (Tomilin, 1951). It must be pointed out that excessive heat loss from flippers and fluke is avoided by a counter-current mechanism, which is characterized by a special blood vessel arrangement so that that the larger arteries are completely surrounded by veins (Schmidt-Nielsen, 1990). This prevents heat from reaching the surface of the appendages. The same mechanism, also found in the legs of seagulls and other birds that swim in cold waters (Steen \& Steen, 1965), transfers heat mainly by conduction from the core to the skin surface through the blubber. The corresponding flux in the steady state is given by:

$$
\mathbf{K}=\frac{k_{\mathrm{B}}}{R \ln (R / r)}\left(T_{\mathrm{B}}-T_{\mathrm{S}}\right)
$$

$\left(\mathrm{W} \cdot \mathrm{m}^{-2}\right)$, where $k_{\mathrm{B}}$ is the thermal conductivity $\left(\mathrm{W} \cdot \mathrm{m}^{-1} \cdot \mathrm{K}^{-1}\right)$ of the blubber layer.

Once stored in the body surface, the heat is transferred by convection to the surrounding water at a rate:

$$
\mathbf{C}=h\left(T_{\mathrm{S}}-T_{\mathrm{W}}\right)
$$

$\left(\mathrm{W} \cdot \mathrm{m}^{-2}\right)$, where $h$ is the coefficient of convection $\left(\mathrm{W} \cdot \mathrm{m}^{-2} \cdot \mathrm{K}^{-1}\right)$.

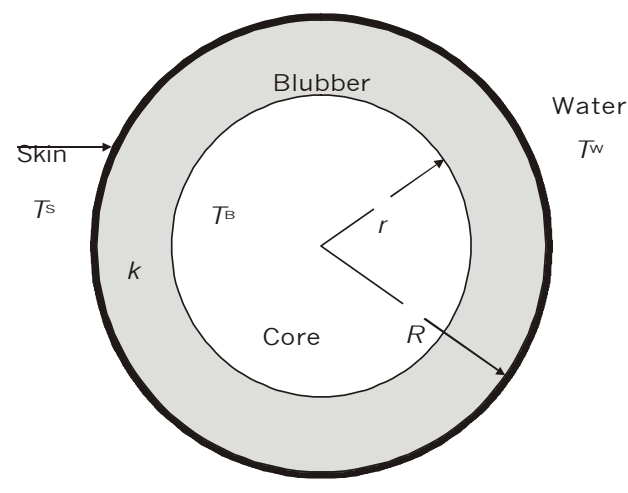

Fig. 1 - Transverse cut of the body of a cetacean, according to the cylindrical model. The core has a temperature $T_{\mathrm{B}}$ and is surrounded by the insulating blubber layer with thermal conductivity $k . T_{\mathrm{S}}$ is the temperature of the skin; $T_{\mathrm{W}}$, the temperature of water. Blubber thickness is given by the difference of the radii $(R-r)$. 
When considering the hydrodynamic and thermodynamic aspects of convection, knowledge of surface temperature, $T_{S}$, for determination of the heat transfer coefficient, $h$, is generally assumed. However, in real problems involving cetaceans neither $T_{\mathrm{s}}$ nor $h$ are known, and it becomes necessary to calculate conduction and convection simultaneously. At the skin surface the convection coefficient $h$ depends on the unknown surface temperature and, in turn, this temperature depends on the heat transfer coefficient. The dependence of $h$ on $T_{\mathrm{S}}$ involves the difference between this temperature and that of the environment.

Hence, it is not possible to calculate temperature directly, and an iterative procedure must be considered. The problem of heat transfer by combined conduction and convection from insulated pipes, comprehensive treatments of which are found in many textbooks, is well known in engineering (e.g., Chapman, 1987). Another problem is the thermal conductivity of blubber. This value and that of blubber thickness are the parameters that determine insulating capacity, or thermal resistance of the blubber layer. Worthy \& Edwards (1990) suggested the value $k_{\mathrm{B}}=0.1 \mathrm{~W} \cdot \mathrm{m}^{-1} \cdot{ }^{\circ} \mathrm{C}^{-1}$ for harbor porpoises, while for whales the usual value is $k_{\mathrm{B}}$ $=0.2 \mathrm{~W} \cdot \mathrm{m}^{-1} .{ }^{\circ} \mathrm{C}^{-1}$ (Innes, 1986; Ryg et al., 1988; Lavigne et al., 1990; Watts et al., 1993). A laboratory experiment by Kvadsheim et al. (1996) showed an average value of $0.25 \mathrm{~W} \cdot \mathrm{m}^{-1} \cdot{ }^{\circ} \mathrm{C}^{-1}$ for minke whales.

Noren et al. (1999) measured experimentally the heat flow at the skin surface of bottlenose dolphins, Tursiops truncatus, resting in warm $\left(28.5^{\circ}\right.$ to $\left.31^{\circ} \mathrm{C}\right)$ water. They obtained a flow of $50 \mathrm{~W} \cdot \mathrm{m}^{-2}$ in the trunk. A consistent result reached by these authors showed that the surface temperature $T_{\mathrm{S}}$ remained within $1^{\circ} \mathrm{C}$ of the water. By using their data and considering the body measurements of the animals observed, we can apply equation (2) to estimate the value of the blubber thermal conductivity as follows:

$k_{\mathrm{B}}=\frac{\mathbf{K} R \ln (R / r)}{T_{\mathrm{B}}-T_{\mathrm{S}}}=\frac{(50)(0.195) \ln (0.195 / 0.183)}{37-31}=$ $=0.1025 \mathrm{~W} \cdot \mathrm{m}^{-1} \cdot{ }^{\circ} \mathrm{C}^{-1}$

This value is very close to that of Worthy \& Edwards (1990).

\section{Iterative procedure}

In order to estimate adequate values for heat flow from the body of a cetacean to its environment an iterative procedure is proposed here, as follows:
1. A trial value of $T_{\mathrm{S}}$ is assumed. For example, in bottlenose dolphins (Tursiops truncatus) the skin temperature remains about $1^{\circ} \mathrm{C}$ above that of the water temperature, $T_{\mathrm{w}}$.

2. The mean temperature $T_{\mathrm{m}}=\left(T_{\mathrm{s}}+T_{\mathrm{w}}\right) / 2$ is calculated. The following thermal properties of the seawater at this temperature are obtained: specific heat $\left(\mathrm{c}_{\mathrm{p}}\right)$, density $(\rho)$, kinematic viscosity $(v)$, and conductivity $(k)$. These properties can be found in Table 1 for temperatures between $-2^{\circ}$ to $35^{\circ} \mathrm{C}$ ( 271.15 to $\left.308.15 \mathrm{~K}\right)$.

3. The following numbers are calculated: the Reynolds, $\mathrm{R}_{\mathrm{e}}=V d \mathrm{v}^{-1}$ and the Prandtl, $\mathrm{P}_{\mathrm{r}}=$ $\rho c_{\mathrm{p}} v k^{-1}$, where $V$ is the swimming speed (m. $\mathrm{s}^{-1}$ ) and $d$ is the characteristic dimension of the body, which in this case is the length (m). The forced convection is considered when the animal is moving through water, otherwise free convection is used, in which case the Grashof number is needed:

$$
\mathrm{G}_{\mathrm{r}}=9.8 d^{3} \mathrm{v}^{-2} \mathrm{~T}_{\mathrm{w}}^{-1}\left(\mathrm{~T}_{\mathrm{s}}-\mathrm{T}_{\mathrm{w}}\right)
$$

where $d$ is the body diameter (m) and all temperatures are in $\mathrm{K}$ degrees.

4. The Nusselt number for forced convection is calculated:

$$
\begin{aligned}
& \mathrm{N}_{\mathrm{u}}=0.664 \mathrm{R}_{\mathrm{e}}^{0,5} \mathrm{P}_{\mathrm{r}}^{1 / 3} \text { for } \mathrm{R}_{\mathrm{e}} \leq 5 \times 10^{5}(5 \mathrm{a}) \\
& \mathrm{N}_{\mathrm{u}}=0.036 \mathrm{R}_{\mathrm{e}}^{0,8} \mathrm{P}_{\mathrm{r}}^{1 / 3} \text { for } \mathrm{R}_{\mathrm{e}}>5 \times 10^{5}(5 \mathrm{~b})
\end{aligned}
$$

or for free convection:

$$
\mathrm{N}_{\mathrm{u}}=\left\{0.6+0.387\left(\mathrm{G}_{\mathrm{r}} \mathrm{P}_{\mathrm{r}}\right)^{1 / 6}\left[1+\left(\frac{0.559}{\mathrm{P}_{\mathrm{r}}}\right)^{9 / 16}\right]^{-8 / 27}\right\}^{2}(6)
$$

5. The coefficient of convection and the convective heat flux is calculated:

$$
\begin{gathered}
h=\frac{k}{d} \mathrm{~N}_{\mathrm{u}}\left(\mathrm{W} \cdot \mathrm{m}^{-2} \cdot \mathrm{K}^{-1}\right) \\
\mathbf{C}=h\left(T_{\mathrm{S}}-T_{\mathrm{W}}\right)
\end{gathered}
$$

6. The overall heat transfer coefficient is calculated: 
$U=\left[\frac{R \ln (R / r)}{k_{\mathrm{B}}}+\frac{1}{h}\right]^{-1}\left(\mathrm{~W} \cdot \mathrm{m}^{-2} \cdot \mathrm{K}^{-1}\right)(8)$

The heat is transferred first from the body core to the skin surface by conduction, and then from the skin to the water by convection. Hence, the convective heat flux can be equated to the total heat flux, as follows:

$$
h\left(T_{\mathrm{S}}-T_{\mathrm{w}}\right)=U\left(T_{\mathrm{B}}-T_{\mathrm{w}}\right)
$$

from which the surface temperature $T_{\mathrm{S}}$ may be estimated.

TABLE 1

Thermophysical properties of marine water according to the temperature (adapted from several tables of Cho et al., 1998).

\begin{tabular}{|c|c|c|c|c|}
\hline $\begin{array}{c}\text { Temperature } \\
{ }^{\circ} \mathrm{C}\end{array}$ & $\begin{array}{c}k \\
\mathbf{W} \cdot \mathrm{m}^{-1} \cdot{ }^{\circ} \mathbf{C}^{-1}\end{array}$ & $\begin{array}{c}\rho \\
\text { kg. } \mathrm{m}^{-3}\end{array}$ & $\begin{array}{c}v \\
10^{-3} \mathrm{~m}^{2} \cdot \mathrm{s}^{-1}\end{array}$ & $\begin{array}{c}\mathrm{C}_{p} \\
\mathrm{~J} \mathrm{~kg}^{-1} \cdot{ }^{\circ} \mathrm{C}^{-1}\end{array}$ \\
\hline-2 & 0.5627 & 1028.4 & 1.91978 & 3.99204 \\
\hline-1.5 & 0.5636 & 1028.4 & 1.89248 & 3.99201 \\
\hline-1 & 0.5645 & 1028.3 & 1.86557 & 3.99197 \\
\hline-0.5 & 0.5654 & 1028.3 & 1.83905 & 3.99194 \\
\hline 0 & 0.5663 & 1028.2 & 1.81292 & 3.99192 \\
\hline 1 & 0.5681 & 1028.1 & 1.76181 & 3.99187 \\
\hline 2 & 0.5699 & 1028.0 & 1.71220 & 3.99184 \\
\hline 3 & 0.5716 & 1027.9 & 1.66408 & 3.99182 \\
\hline 4 & 0.5734 & 1027.7 & 1.61742 & 3.99181 \\
\hline 5 & 0.5751 & 1027.6 & 1.57219 & 3.99181 \\
\hline 6 & 0.5768 & 1027.5 & 1.52836 & 3.99183 \\
\hline 7 & 0.5786 & 1027.3 & 1.48591 & 3.99186 \\
\hline 8 & 0.5803 & 1027.1 & 1.44481 & 3.99190 \\
\hline 9 & 0.5819 & 1027.0 & 1.40504 & 3.99195 \\
\hline 10 & 0.5836 & 1026.8 & 1.36656 & 3.99201 \\
\hline 11 & 0.5853 & 1026.6 & 1.32935 & 3.99209 \\
\hline 12 & 0.5869 & 1026.4 & 1.29339 & 3.99218 \\
\hline 13 & 0.5885 & 1026.2 & 1.25865 & 3.99228 \\
\hline 14 & 0.5901 & 1026.0 & 1.22510 & 3.99239 \\
\hline 15 & 0.5917 & 1025.7 & 1.19272 & 3.99252 \\
\hline 16 & 0.5933 & 1025.5 & 1.16147 & 3.99265 \\
\hline 17 & 0.5949 & 1025.3 & 1.13134 & 3.99280 \\
\hline 18 & 0.5964 & 1025.0 & 1.10229 & 3.99296 \\
\hline 19 & 0.5980 & 1024.8 & 1.07431 & 3.99314 \\
\hline 20 & 0.5995 & 1024.5 & 1.04735 & 3.99332 \\
\hline 21 & 0.6010 & 1024.2 & 1.02141 & 3.99352 \\
\hline 22 & 0.6025 & 1024.0 & 0.99644 & 3.99373 \\
\hline 23 & 0.6040 & 1023.7 & 0.97243 & 3.99395 \\
\hline 24 & 0.6055 & 1023.4 & 0.94934 & 3.99419 \\
\hline 25 & 0.6069 & 1023.1 & 0.92716 & 3.99443 \\
\hline 23 & 0.6084 & 1022.8 & 0.90585 & 3.99469 \\
\hline 27 & 0.6097 & 1022.5 & 0.88539 & 3.99496 \\
\hline 28 & 0.6112 & 1022.1 & 0.86575 & 3.99524 \\
\hline 29 & 0.6126 & 1021.8 & 0.84690 & 3.99554 \\
\hline 30 & 0.6140 & 1021.5 & 0.82882 & 3.99585 \\
\hline
\end{tabular}

$k=$ thermal conductivity; $\rho=$ density; $v=$ kinematic viscosity; and $c_{p}=$ specific heat 
7. The surface temperature is calculated:

$$
T_{\mathrm{S}}=\frac{U T_{\mathrm{B}}+T_{\mathrm{w}}(h-U)}{h}
$$

The result is compared with the initial assumption for $T_{\mathrm{S}}$, a revised value of $T_{\mathrm{S}}$ is chosen, and all calculations are repeated. The process continues until the results converge and a satisfactory agreement between two successive $T_{\mathrm{S}}$ values is achieved. The extent to which the iterative process is carried out depends on desired accuracy. In general, less than 10 iterations may be needed until adequate convergence is reached.

The difference $\Delta T$ between the skin temperature estimated by equation 10 and that of the water linearly decrease with water temperature, as shown in Fig. 2. For example, at $T_{\mathrm{w}}=0^{\circ} \mathrm{C}$ the skin temperature is $7.8^{\circ} \mathrm{C}$ while it is $31.3^{\circ} \mathrm{C}$ for $T_{\mathrm{w}}=30^{\circ} \mathrm{C}$. Experimental data recorded by Noren et al. (1999) showed that $\Delta T$ remained at around $1^{\circ} \mathrm{C}$ for $T_{\mathrm{w}}$ values between $28^{\circ}$ and $31^{\circ} \mathrm{C}$ with a linear association. It is noteworthy that these results are in accordance with the values predicted by equation 10 , despite the lack of experimental evidence for cold-water conditions.

The estimated body surface temperature can be used to determine heat loss by convection and conduction as follows:
1. $T_{\mathrm{m}}=\left(T_{\mathrm{S}}+T_{\mathrm{w}}\right) / 2$ is calculated. The thermophysical properties of water at that temperature are obtained (Table 1).

2. The Nusselt number, $\mathrm{N}_{\mathrm{u}}$, is calculated.

3. The rate of convective loss, $\mathrm{C}=k \mathrm{~L}^{-1} \mathrm{~N}_{\mathrm{u}}\left(T_{\mathrm{S}}-\right.$ $\left.T_{\mathrm{w}}\right), \mathrm{W} \cdot \mathrm{m}^{-2}$ is calculated.

If the heat lost by respiration is negligible and a thermal equilibrium steady state can be assumed, then the rate of heat loss by convection calculated as above is also an estimate of the rate of metabolic heat production $(\mathbf{M})$.

\section{Example}

Suppose a dolphin, $2.5 \mathrm{~m}$ in length and 0.37 $\mathrm{m}$ in maximum body diameter, is swimming at a 10 knot speed $\left(5.1 \mathrm{~m} . \mathrm{s}^{-1}\right)$ in $18^{\circ} \mathrm{C}$ water. The blubber has an average thickness of $1.23 \mathrm{~cm}$ and deep body temperature is $37^{\circ} \mathrm{C}$.

\section{Solution}

Assuming an initial value $T_{\mathrm{S}}=20^{\circ} \mathrm{C}$, the average temperature is $T_{\mathrm{m}}=(20+18) / 2=19^{\circ} \mathrm{C}$. In Table 1 , the thermophysical properties of the water are found for this temperature: $\rho=1024.8 \mathrm{~kg} \cdot \mathrm{m}^{-3}, \mathrm{c}_{\mathrm{p}}=$ $3.99314 \mathrm{~J} \mathrm{~kg}^{-1} .{ }^{\circ} \mathrm{C}^{-1}, k=0.5980 \mathrm{~W} \cdot \mathrm{m}^{-1} .{ }^{\circ} \mathrm{C}^{-1}$, and $\mathrm{v}=$ $1.07431 \times 10^{-3} \mathrm{~m}^{2} . \mathrm{s}^{-1}$.

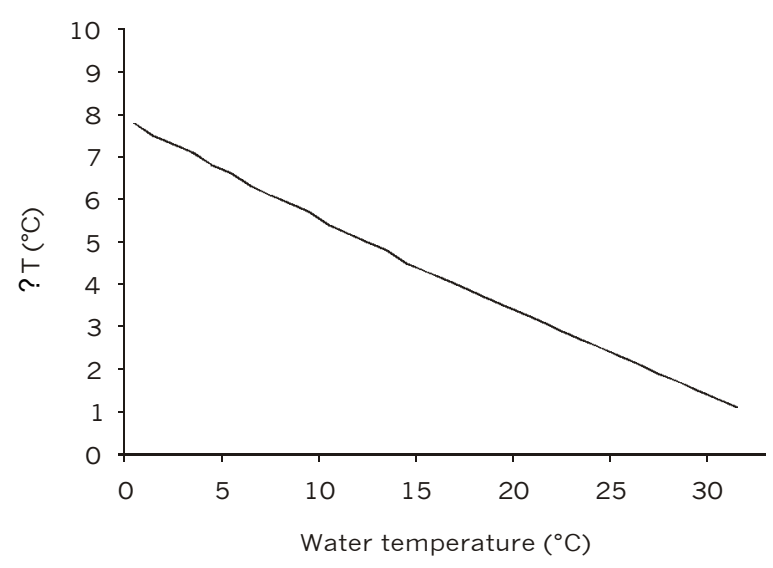

Fig. 2 - Difference between water temperature and skin temperature $(\Delta T)$ in cetaceans, as estimated by the iterative method. 
Then:

$$
\begin{aligned}
& \mathrm{R}_{\mathrm{e}}=V \cdot L \cdot v^{-1}=(5.1)(2.5)\left(1.07431 \times 10^{-3}\right)^{-1}=11,868.08 \\
& \mathrm{P}_{\mathrm{r}}=\rho c_{\mathrm{p}} v k^{-1}=(1,024.8)(3.99314)\left(1.07431 \times 10^{-3}\right) / 0.5980=7.351604 \\
& \mathrm{~N}_{\mathrm{u}}=0.664 \mathrm{R}_{\mathrm{e}}^{0.5} \mathrm{P}_{\mathrm{r}}^{1 / 3}=0.664(11,868.08)^{0.5}(7.351604)^{1 / 3}=140.654 \\
& h=k L^{-1} \mathrm{~N}_{\mathrm{u}}=0.598(2.5)^{-1}(140.654)=33.644 \\
& U=\left[\frac{R \ln (R / r)}{k_{B}}+\frac{1}{h}\right]^{-1}=\left[\frac{0.185 \ln (0.185 / 0.173)}{0.1025}+\frac{1}{33.644}\right]^{-1}=6.632807 \\
& T_{\mathrm{S}}=\frac{U T_{\mathrm{B}}+T_{\mathrm{W}}(h-U)}{h}=\frac{(6.632807)(37)+18(33.644-6.632807)}{33.644}=21.746^{\circ} \mathrm{C}
\end{aligned}
$$

After four iterations the results converged to the value $T_{\mathrm{S}}=21.647^{\circ} \mathrm{C}$, for which the coefficient of convection $h=33.841 \mathrm{~W} \cdot \mathrm{m}^{-2} .{ }^{\circ} \mathrm{C}^{-1}$ was calculated and used to compute the heat loss by convection:

$\mathrm{C}=h\left(T_{S}-T_{W}\right)=33.841(21.647-18)=123.42 \mathrm{~W} \cdot \mathrm{m}^{-2}$

Thus, in order to sustain thermal balance in the given environmental conditions the animal must have a metabolic rate of the same level as that of the heat loss $(\mathbf{C})$.

The above-described procedure would be useful in behavioral studies, when the handling of the animals and even excessively close watching must be avoided. Using a $\mathrm{C}++$ program allows the carrying out of all needed calculations. This program is available on request from the author.

\section{REFERENCES}

BOYD, I. L., 2000, Skin temperatures during free-ranging swimming and diving in Antarctic fur seals. J. Exper. Biol., 203: 1907-1914.

CHAPMAN, A. J., 1987, Fundamentals of heat transfer. Macmillan, New York, Chapter 10, pp. 560-571.

CHO, Y. I., GANIC, E. N., HARTNETT, J. P. \& ROHSENOW, W. M., 1998, Basic concepts of heat transfer, pp. 1.1-1.37. In: W. M. Rohsenow, J. P. Hartnett \& Y. I. Cho (eds.), Handbook of heat transfer. $3^{\text {rd }}$ ed. McGraw-Hill, New York.

FOLKOW, L. P. \& BLIX, A. S., 1992, Metabolic rates of minke whales, Balaenoptera acutorostrata, in cold water. Acta Physiol. Scand., 142: 141-150.

HOKKANEN, J. E., 1990, Temperature regulation of marine mammals. J. Theor. Biol., 145: 465-485.

INNES, S., 1986, How fast should a dead whale cool? Can. J. Zool., 64: 2064-2065.

IRVING, L. \& HART, J. S., 1957, The metabolics and insulation of seals as bare-skinned mammals in cold water. Can. J. Zool., 35: 497-511.

KANWISCHER, J. \& LEIVESTAD, H., 1957, Thermal regulation in whales. Norsk Hvalfangst-tid., 1: 1-5.
KANWISCHER, J. \& SUNDNES, G., 1966, Thermal regulation in cetaceans, pp. 397-407. In: K. S. Norris (ed.), Whales, Dolphins and Porpoises. Univ. California Press, Berkeley.

KSHATRIYA, M. \& BLAKE, R. W., 1988, Theoretical model of migration energetics in the blue whale, Balaenoptera musculus. J. Theor. Biol., 133: 479-498.

KVADSHEIM, P. H., FOLKOW, L. P. \& BLIX, A. S., 1996, Thermal conductivity of minke whale blubber. $J$. Thermal Biol., 21: 123-128.

LAVIGNE, D. M., INNES, S., WORTHY, G. A. J. \& EDWARDS E. F., 1990, Lower critical temperatures of blue whales, Balaenopterus musculus. J. Theor. Biol., 144: 249-257.

MORRISON, P., 1962, Body temperatures in some Australian mammals. III. Cetacea (Megaptera). Biol. Bull., 123: 154169.

NOREN, D. P., WILLIAMS, T. M., BERRY, P. \& BUTLER, E., 1999, Thermoregulation during swimming and diving in bottlenose dolphins, Tursiops truncatus. J. Comp. Physiol. B., 169: 93-99.

RYG, M., SMITH, T. G. \& ØRITSLAND, N. A., 1988, Therma significance of the topographical distribution of blubber in ringed seals (Phoca hispida). Can. J. Fish. Aquat. Sci., 45: 985-992.

SCHMIDT-NIELSEN, K., 1990, Animal physiology: adaptation and environment. $4^{\text {th }}$ ed. Cambridge Univ. Press, Cambridge, $602 \mathrm{p}$.

SCHOLANDER, P. F., WALTERS, V., HOCK, R. \& IRVING L., 1950, Body insulation of some artic and tropical mammals and birds. Biological Bulletin, 99: 225-236.

STEEN, I. \& STEEN, J. B., 1965, The importance of the legs in the thermoregulation of birds. Acta Physiol. Scand., 63 285-291.

TOMILIN, A. G., 1951, On the thermal regulation in cetaceans. Priroda, 6: 55-58.

WATTS, P., HANSEN, S. \& LAVIGNE, D. M., 1993, Models of heat loss by marine mammals: thermoregulation below the zone of irrelevance. J. Theor. Biol., 163: 505-525.

WORTHY, G. A. \& EDWARDS, E. F., 1990, Morphometric and biochemical factors affecting heat loss in a small temperate cetacean (Phocoena phocoena) and a small tropical cetacean (Stenella attenuata). Physiol. Zool., 63: 432-442. 